\title{
PELATIHAN PENULISAN KARYA TULIS ILMIAH BAGI GURU SMK MUHAMMADIYAH
}

\author{
Dedy Hermanto Karwan ${ }^{1}$, Hasan Hariri ${ }^{2}$ \\ Fakultas Keguruan dan Ilmu Pendidikan, Universitas Lampung \\ Jl. Prof. Sumantri Brojonegoro No.1 Bandar Lampung 35145 \\ Penulis Korespodensi : hasan.hariri@ staff.unila.ac.id
}

\begin{abstract}
Abstrak
Kegiatan pengabdian kepada masyarakat ini adalah secara khusus ditujukan kepada guru-guru Sekolah Menengah Kejuruan (SMK) Muhammadiyah Provinsi Lampung, yang secara umum perlu ditingkatkan pengetahuan dan kemampuannya dalam menulis artikel ilmiah yang merupakan salah satu unsur penting dalam pengembangan keprofesian berkelanjutan (PKB) guru. Tujuan kegiatan ini adalah untuk (1) memberikan pengetahuan dan pemahaman tentang cara-cara menulis karya ilmiah khususnya artikel jurnal nasional, (2) membantu guru menghasilkan karya ilmiah berupa naskah artikel tentang pendidikan sesuai bidang dan program keahlian mereka di sekolah untuk layak terbit setidak-tidaknya pada jurnal nasional.Pelatihan ini diawali dengan penjelasan disertai contoh-contoh (dari judul, latar belakang, metode, hasil, pembahasan, kesimpulan, implikasi, dan referensi). Selanjutnya peserta diberi tugas latihan menulis dengan topik sesuai minat mereka dan dibawa pulang, dan setelah lima hari bertemu lagi dengan membawa hasil tulisan mereka. Secara umum perubahan pengetahuan dan kemampuan sebagai hasil pelatihan, yaitu peserta dapat meningkatkan pengetahuan dan kemampuan menulis karya ilmiah, dibandingkan sebelum pelatihan, berdasarkan kenaikan skor rata-rata yang meningkat dan hasil interview setelah mengikuti proses pelatihan.
\end{abstract}

Kata kunci:Guru, Karya Ilmiah, Pelatihan, Penulisan

\section{Pendahuluan}

Menyusun Karya Tulis Ilmiah (KTI) merupakan salah satu bentuk kegiatan pengembangan profesi guru. Pengembangan profesi terdiri atas 5 (lima) macam kegiatan, yaitu:

(1) menyusun Karya Tulis Ilmiah (KTI),

(2) menemukan teknologi tepat guna,

(3) membuat alat peraga/bimbingan,

(4) menciptakan karya seni, dan

(5) mengikuti kegiatan pengembangan kurikulum.

Para guru diharapkan mampu menyusun karya tulis ilmiah sebagai salah satu kegiatan pengembangan profesinya. Tetapi pada kenyataannya, sebagian guru termasuk guru SMK Muhammadiyah di Provinsi Lampung masih mengalami kesulitan. Ada berbagai permasalahan yang menghambat para guru SMK Muhammadiyah tersebut mengalami kesulitan dalam menyusun KTI. Salah satu permasalahan itu adalah bahwa para guru masih kekurangan infomasi tentang caracara menulis karya ilmiah, terutama untuk menulis artikel ilmiah pada jurnal. Hal itu mengakibatkan para guru sulit dalam mengembangkan profesi dan berdampak kepada inovasi pembelajaran dan kenaikan pangkat (Suhardjono, 2006; Ritonga \& Iskandar, 2018). Rendahnya tingkat keberhasilan guru dalam proses kenaikan pangkat tersebut disebabkan oleh faktor kelemahan guru dalam penyusunan karya tulis, yang tidak memenuhi persyaratan minimal sebagai karya ilmiah (Sudjana \& Laksana, 2001).

Pada dasarnya guru mempunyai segudang ide untuk diungkapkan. Salah satunya bersumber dari permasalahan yang ada di sekitarnya, khususnya dalam proses pembelajaran di kelas, namun guru kurang memahami dan akhirnya belum dapat menuangkannya ke dalam sebuah karya tulis ilmiah yang layak untuk dipublikasikan dan dikonsumsi masyarakat luas (Dwipayana, 2003).

Karya tulis ilmiah hasil penelitian, pengkajian, survei dan evaluasi, karya tulis/makalah berupa tinjauan atau ulasan ilmiah hasil gagasan sendiri, tulisan ilmiah populer, prasaran berupa tinjauan wawasan atau ulasan ilmiah yang disampaikan pada pertemuan ilmiah, buku pelajaran atau modul, diktat pelajaran, menerjermahkan karya ilmiah, skripsi, tesis, buku, 
paper, artikel, dan berbagai produk lain yang dapat dipublikasikan (Muslich, 2012).

Setiap produk penulisan atau penelitian masyarakat akademik idealnya berorientasi untuk dipublikasikan agar dapat menggugah masyarakat akademik untuk selalu berkarya. Masyarakat akademik inilah yang berkepentingan untuk pengembangan ilmu pengetahuan dan teknologi serta pemecahan berbagai permasalahan yang dihadapi masyarakat (Santoso, 2007). Karya tulis ilmiah merupakan tulisan yang berisi gagasan kreatif yang disusun secara komprehensif berdasarkan data akurat, dianalisis secara runtut, tajam dan diakhiri dengan kesimpulan yang relevan.

Oleh sebab itu, penulisan karya tulis ilmiah diharapkan memenuhi aspek-aspek (1) relevan dengan situasi dan kondisi yang ada, (2) mempunyai pokok permasalahan yang jelas, (3) masalah dibatasi, sesempit mungkin (Firmansyah, 2007).

Selanjutnya, Santoso (2007) menegaskan bahwa masyarakat akademik inilah yang berkepentingan untuk pengembangan ilmu pengetahuan dan teknologi serta pemecahan berbagai permasalahan yang dihadapi masyarakat. Karya tulis ilmiah yang ditulis guru hendaknya memenuhi syarat-syarat sebagai berikut:

a) Asli (original), bukan karya jiplakan dan menjauhi duplikasi, yaitu karya tulis yang dihasilkan harus merupakan produk asli guru dan sesuai dengan bidang ilmu yang dimiliki serta permasalahan yang dihadapi di lingkungannya;

b) Bermanfaat, yaitu karya tulis yang dihasilkan guru harus dirasakan manfaatnya secara langsung oleh guru dalam meningkatkan kualitas pembelajaran;

c) Ilmiah, yaitu karya tulis yang dihasilkan harus disusun secara ilmiah, sistimatis, runtut, dan memenuhi persyaratan penulisan karya ilmiah;

d) Konsisten, yaitu yang dihasilkan harus memperlihatkan keajegan dan konsistensi pemikiran yang utuh, baik secara keseluruhan maupun hubungan antarbab bagian karya tulis yang disajikan (Aina, dkk., 2015).

Perlu juga diperhatikan mengenai sifat dan isi tulisan dari sebuah karya tulis ilmiah sebagai berikut: a) kreatif dan objektif, dimaksudkan agar tulisan tetap memperhatikan gagasan yang kreatif untuk mensolusikan suatu permasalahan yang berkembang di masyarakat,

b) tulisan tidak bersifat emosional atau tidak menonjolkan permasalahan subjektif, tulisan didukung oleh data dan atau informasi terpercaya,

c) materi karya tulis ilmiah disusun secara logis, sistematis, serta merupakan isu mutakhir (Nurudin, 2007; Rosmiati, 2017).

Selain perlu mempertimbangkan persyaratan tersebut, karya tulis ilmiah menuntut motivasi dan disiplin yang tinggi, kemampuan berbahasa, peka terhadap perkembangan pengetahuan, serta mengikuti pedoman penulisan yang berlaku. Jika seorang guru dapat mengembangkan kemampuannya menulis karya ilmiah, manfaat yang dapat diperoleh antara lain:

1)melatih mengembangkan keterampilanmembaca,

2) melatih menulis dari berbagai sumber dan mengembangkannya ke tingkat pemikiran yang lebih matang,

3) memperluas cakrawala ilmu pengetahuan, dan memperoleh kepuasan intelektual, dan

4) menambah kredit point bagi guru (Djuroto \& Supriyadi, 2007). 


\section{Metode}

Metode yang digunakan dalam pelatihan ini adalah ceramah, tanya jawab, diskusi, pelatihan, dan presentasi. Pelatihan ini sangat bermanfaat bagi peserta dalam upaya mengembangkan profesinya untuk menyusun karya tulis ilmiah yang bermutu.Para guru tersebut mendapatkan pengetahuan dan wawasan yang lebih luas tentang karya sesuai bidang keahlian mereka yang memiliki karakteristik tertentu, tetapi masih teridentifikasi bahwa mereka memiliki permaslahan dalam menulis karya ilmiah.Secara khusus, metode pelaksanaan juga dilakukan sebagai berikut.

\section{a. Identifikasi dan Perumusan Masalah}

Berdasarkan analisis situasi dan landasan teori tersebut di atas dan kenyataan di lapangan, dapat diidentifikasi beberapa permasalahan sebagai berikut:

1) Sebagian guru SMK Muhammadiyah di Provinsi Lampung masih mengalami kesulitan dalam penulisan karya tulis ilmiah, 2) Sebagian guru SMK Muhammadiyah di Provinsi Lampung masih kurang infomasi tentang cara-cara menulis karya ilmiah terutama untuk menulis artikel ilmiah pada jurnal, 3) Sebagian guru SMK Muhammadiyah di Provinsi Lampung masih mengalami kekurangan informasi bagaimana mempublikasikan karya tulis mereka pada jurnal baik jurnal nasional maupun jurnal internasional, 4) Menulis karya ilmiah memerlukan cara-cara ilmiah yang baik agar terhindar dari plagiarisme, fabrikasi, dan berbagai perilaku yang menyimpang dari etika ilmiah lainnya sehingga diperlukan suatu kegiatan khusus.

\section{b. Kerangka Pemecahan Masalah}

Menulis karya ilmiah memerlukan cara-cara ilmiah yang baik.Hal ini dilakukan agar karya ilmiah dapat terhindar dari plagiat, fabrikasi, dan berbagai perilaku yang menyimpang dari etika ilmiah lainnya.Melihat hal tersebut perlu kiranya ada sebuah pelatihan khusus bagi para guru untuk menyusun karya tulis ilmiah yang dapat dipublikasikan dalam jurnal ilmiah.Selain itu, perlu juga untuk disosialisasikan keberadaan jurnaljurnal yang yang merupakan jurnal target untuk agar mereka mengetahui bagai mana mereka bisa menerbitkan pada jurnal-jurnal tersebut.
Kegiatan pelatihan penulisan karya ilmiah ini melaksanakan evaluasi melalui observasi partisipatif pada saat kegiatan dilaksanakan.Kriteria, indikator dan tolak ukur evaluasi ini adalah penguasaan materi pelatihan, kesungguhan dalam pelatihan, kemampuan menghasilkan karya tulis ilmiah artikel untuk jurnal.

Evaluasi ini dilakukan dengan melaui tiga tahap yaitu:

(1) Evaluasi awal yang bertujuan untuk mengetahui pemahaman dan kemampuan peserta pelatihan, evaluasi awal ini menggunakan pre-test,

(2) Evaluasi proses bertujuan untuk mengetahui kesungguhan dalam mengikuti pelatihan, evaluasi ini menggunakan lembar observasi, dan

(3) Evaluasi akhir yaitu bertujuan untuk mengetahui hasil pelatihan yang telah dilakukan.

Peserta diberikan post-test yang berupa masalah yang harus dipecahkan, hasil dari evaluasi tahap tiga ini adalah untuk mengetahui tingkat pemahaman dan perubahan pada peserta pelatihan. Hal ini adalah upaya mendorong peserta agar dapat mengaplikasikan materi pada hari pertama, meskipun sebenarnya relatif masih kurang waktu untuk mendapatkan materi dalam waktu satu hari.

Oleh karen itu, peserta diberi sampel artikel disertai manual bagi penulis dari jurnal tertentu dan dilengkapi templatenya sebagai pedoman bagi mereka dalam menulis artikel. Hal ini dilakukan untuk membantu mereka mengurangi kebingungan dalam menulis.Untuk meningkatkan pengetahuan mereka dalam menulis artikel, peserta diminta untuk memperesentasikan naskah/draf artikel pada hari terkahirb pelatihan.Narasumber memberikan feedback terkait artikel yang mereka tulis dan presentasikan.

Organisasi pelaksana adalah meliputi seluruh penulis artikel pengabdian ini yang dilaksanakan di Bandar Lampung dengan rentang waktu 10 s.d. 16 Oktober. Dua kali pertemuan di kelas: tanggal 10 Oktober 2018 adalah pertemuan awal dan tanggal 16 Oktober 2018 adalah pertemuan terkahir. Antara pertemuan awal dan pertemuan akhir tersebut, peserta diberikan waktu untuk berlatih menulis artikel ilmiah, serta bimbingan melalui media komunikasi dengan nara sumber atau pelatih. 


\section{Hasil dan Pembahasan}

Kegiatan pelatihan penulisan karya ilmiah guru SMK Muhammadiyah di Provinsi Lampung diikuti sebanyak 29 orang guru dari 30 orang yang diundang. Untuk mengetahui efektivitas keberhasilan kegiatan tersebut dilakukan proses dan penilaian hasil dengan menggunakan tes awal dan akhir. Disamping diberi materi di kelas terkait bagaimana menulis artikel dan bagaimana mempublikasikan pada jurnal, peserta juga dberi tugas mandiri di luar kelas menyusun proposal karya ilmiah. Hasil tugas mandiri selanjutkan dibahas di kelas. Peserta diberi kesempatan melakukan presentasi, dan narasumber memberi masukan kepada para peserta untuk memperbaiki draf karya ilmiah.

\section{a. Faktor Pendukung dan Penghambat}

Faktor yang mempengaruhi kegiatan pengabdian ini meliputi faktor pendukung dan faktor penghambat. Faktor pendukung pelaksanaan kegiatan pengabdian berupa pelatihan ini didukung oleh beberapa faktor yang memberikan banyak kontribusi atas keberhasilan kegiatan PkM. Faktorfaktor tersebut adalah:

1) sumber daya manusia fasilitator, sumber daya manusia dalam hal ini adalah para dosen yang terlibat dalam kegiatan PkM merupakan orangorang terlibat dan sering menulis karya ilmiah,

2) Sarana Prasarana, Kegiatan PkM ini sangat didukung oleh sarana prasarana pelatihan yang cukup lengkap (dukungan dari Majelis Dikdasmen PW Muhamadiah).

Sedangkan faktor penghambat dalam pelaksanaan kegiatan PkM ini dapat diperkecil sedemikian rupa sehingga seluruh kegiatan PkM dapat berjalan dengan baik. Satu guru yangdiundang tidak datang dikarenakan berbenturan dengan jadwal mengajar di sekolahnya.

Pengabdian pada masyarakat ini melalui tahapan:

1) Penyajian informasi dan diskusi. Kegiatan ini merupakan upaya untuk mengembangkan wawasan teoretis para peserta tentang konsep karya ilmiah melalui penjelasan yang dilengkapi dengan berbagai isu/contoh yang berkembang di lapangan, untuk mempertajam pemahaman mereka, maka dilakukan dialog dan diskusi baik yang langsung berhubungan dengan materi yang sedang disajikan maupun yang berhubungan dengan masalah kebijakan,

2) Menyelenggarakan responsi dan diskusi kelompok tentang materi yang telah diinformasikan sebelumnya. Hal ini tidak hanya dimaksudkan untuk memperjelas dan mepertegas materi yang telah dibahas, tetapi juga untuk meningkatkan ketajaman para peserta dalam menganalisis permasalahan secara operasional dalam diskusi kelompok,

3) Mengadakan latihan penulisan ilmiah secara praktis yang didasarkan pada bidang mereka masing-masing,

4) Melaksanakan evaluasi untuk mengetahui pencapaian program kegiatan pengabdian pada masyarakat yang meliputi: proses kegiatan informasi dan diskusi kelompok serta hasil simulasi dari para peserta.

Adapun gambaran kerangka pemecahan masalah adalah sebagai berikut:

Tabel 1 Kerangka Pemecahan Masalah

\begin{tabular}{|c|c|c|}
\hline Situasi Sekarang & $\begin{array}{l}\text { Pemberian } \\
\text { Perlakuan }\end{array}$ & $\begin{array}{l}\text { Situasi yang } \\
\text { Diinginkan }\end{array}$ \\
\hline $\begin{array}{l}\text { Para guru di } \\
\text { wilayah Dinas } \\
\text { Pendidikan } \\
\text { Provinsi } \\
\text { Lampung belum } \\
\text { sepenuhnya } \\
\text { memahami } \\
\text { konsep penulisan } \\
\text { karya ilmiah } \\
\end{array}$ & $\begin{array}{l}\text { Pemberian } \\
\text { penngetahuan } \\
\text { tentang } \\
\text { konsep } \\
\text { penilaian } \\
\text { penulisan } \\
\text { karya ilmiah }\end{array}$ & $\begin{array}{l}\text { Para guru } \\
\text { memahami } \\
\text { konsep } \\
\text { penulisan karya } \\
\text { ilmiah }\end{array}$ \\
\hline $\begin{array}{l}\text { Para guru masih } \\
\text { kurang } \\
\text { keterampilannya } \\
\text { dalam } \\
\text { mengimplementa } \\
\text { sikan konsep } \\
\text { penulisan karya } \\
\text { ilmiah }\end{array}$ & $\begin{array}{l}\text { Diskusi, dan } \\
\text { latihan } \\
\text { pemecahan } \\
\text { masalah yang } \\
\text { berhubungan } \\
\text { dengan konsep } \\
\text { penulisan } \\
\text { karya ilmiah }\end{array}$ & $\begin{array}{l}\text { Para guru } \\
\text { meningkatkan } \\
\text { keterampilan } \\
\text { dalam } \\
\text { pemecahan } \\
\text { masalah tentang } \\
\text { konsep } \\
\text { penulisan karya } \\
\text { ilmiah }\end{array}$ \\
\hline $\begin{array}{l}\text { Para guru masih } \\
\text { kurang memiliki } \\
\text { keterampilan } \\
\text { dalam } \\
\text { melaksanakan } \\
\text { penulisan karya } \\
\text { ilmiah } \\
\end{array}$ & $\begin{array}{l}\text { Diskusi, dan } \\
\text { latihan dalam } \\
\text { melaksanakan } \\
\text { penulisan } \\
\text { karya ilmiah }\end{array}$ & $\begin{array}{l}\text { Para guru } \\
\text { meningkatkan } \\
\text { keterampilan } \\
\text { dalam penulisan } \\
\text { karya ilmiah }\end{array}$ \\
\hline
\end{tabular}


Untuk mengetahui perolehan pelatihan dilakukan evaluasi yang satu diantaranya adalah penilaian pengetahuan. Soal tes awal dan tes akhir adalah sama. Tes awal diujikan kepada peserta pelatihan untuk mengetahui kemampuan awal mereka sehingga narasumber mengetahui materi yang sesuai untuk dilatihkan kepada peserta.

Tes akhir dilakukan untuk mengetahui seberapa jauh kemampuan peserta setelah mendapatkan pelatihan dibandingkan sebelum diberikan pelatihan.Jumlah soal tes adalah sebanyak 35 dengan skor masing-masing soal adalah 1 untuk jawaban yang benar. Hasil skor penilaian tes awal dan tes akhir adalah sebagai berikut, skor tertinggi pada pre-test 74 , terendah 26 dan rata-rata 52, sedangkan skor tes akhir tertinggi 94 dan terendah 46 dan rata-rata 65.

\section{Kesimpulan dan Rekomendasi}

Dari hasil pelaksanaan melalui tahapan penyampaian materi pelatihan, diskusi kelompok, tes awal dan tes akhir dapat disimpulkan sebagai berikut:

Secara umum perubahan pengetahuan hasil pelatihan pemahaman tetang pengetahuan Karya Tulis Ilmiah peserta meningkat jika dibandingkan sebelumnya berdasarkan kenaikan skor rata-rata meningkat setelah mengikuti proses pelatihan.

Penilaian kemampuan penulisan karya ilmiah guru pada SMK Muhammadiyah di Provinsi Lampung sangat penting dan strategis serta berpengaruh pada motivasi guru dalam melaksanakan tugas dan fungsinya, sehingga diperlukan tindak lanjut melalui workshop kepada semua guru agar dapat menjamin terwujudnya sekolah yang efektif dan menjadikan guru SMK Muhammadiyah senantiasa belajar dalam menyiapkan diri agar lebih profesional, khususnya dalam menulis karya ilmiah.

Setiap lembaga pemerintah dan organisasi serta stakeholder yang bertanggung jawab terhadap penyiapan dan pembinaan guru khususnya, berkewajiban secara terus-menerus melakukan fungsinya agar terjadi akselerasi peningkatan kauntitas dan kualitas guru SMK Muhammadiyah dalam melaksanakan tugasnya secara efektif dan berdampak positif terhadap karir terutama dalam hal kenaikan pangkat dari hasil pengetahuan dan keterampilan menulis karya ilmiah.

\section{Ucapan Terima Kasih}

Terima kasih kami sampaikan kepada LPPM Unila yang telah mendanai kegiatan pengabdian kepada masyarakat ini, dan semua pihak terutama DPW Muhammadiyah beserta jajarannya yang telah banyak membantu terselenggaranya kegiatan pengabdian ini.

\section{Daftar Pustaka}

Aina, M., Bambang, H., Retni, S. B., Afreni, H., \& Sadikin, A. (2015). Pelatihan penulisan karya tulis ilmiah bagi guru guru SMA 8 Kota Jambi. Jurnal Pengabdian pada Masyarakat, $30(3)$.

Djuroto, T., dan Supriyadi, B. 2007. Menulis Artikel dan Karya Ilmiah. Bandung: Remaja Rosda Karya.

Dwipayana, A. (2003). Kiat Menulis di Media. Jakarta: Global Mahardika Netama.

Firmansyah, D. (2007). Pedoman Penulisan Karya Tulis Ilmiah. Disampaikan dalam Pelatihan "Sukses membuat Proposal Penelitian yang Bermutu”. FMIPA Universitas Negeri Surabaya, 8 Desember 2007.

Muslich, M. (2012). Melaksanakan PTK itu Mudah. Jakarta: Bumi Aksara

Nurudin.(2007). Dasar-Dasar Penulisan. Malang: UMM Press.

Rosmiati, A. (2017) Dasar-Dasar Penulisan Karya Ilmiah. Surakarta: Isi Press. Diakses pada 5 Februari 2018 dari http://repository. isiska.ac.id/1395/3/DasarDasar\%20Penulisan\%20Ilmiah.pdf.

Santoso, S. (2007). Kiat dan Strategi Menulis Karya Ilmiah.Universitas Negeri Jakarta.Makalah Disampaikan pada Pelatihan Penulisan Karya Tulis Ilmiah bagi DosenDosen PPSMK Muhammadiyah FIP UNY.

Sudjana, N. \& Laksana, U. (2001). Menyusun Karya Tulis Ilmiah untuk 
Memperoleh Angka Kredit. Badung: Sinar Baru Algesindo

Suhardjono. (2006). Peningkatan Karir Tenaga Kependidikan Khusunya dalam Hal Pembuatan Karya Tulis Ilmiah sebagai Kegiatan Pengembangan Profesi.Makalah, Disampaikan pada Temu Konsultasi dalam Rangka Koordinasi dan Pembinaan
Kepegawaian Pendidik dan Tenaga Kependidikan di Griya Astuti, November 2006.

Ritonga, R., \& Iskandar, R. (2018). Penulisan karya tulis ilmiah bagi guru sekolah dasar di karawang. Jurnal Pengabdian Masyarakat (JPM-IKP), 1(01).doi: https://doi.org/ 10.31326/jmp-ikp.v1i01.75. 